Cornell Law Library

Scholarship@Cornell Law: A Digital Repository

Cornell Law Faculty Publications

Faculty Scholarship

$8-2004$

\title{
Real Time: Unwinding Technocratic and Anthropological Knowledge
}

Annelise Riles

Cornell Law School, ar254@cornell.edu

Follow this and additional works at: http://scholarship.law.cornell.edu/facpub

Part of the Legal History, Theory and Process Commons, Political Theory Commons, and the Social and Cultural Anthropology Commons

\section{Recommended Citation}

Riles, Annelise, "Real Time: Unwinding Technocratic and Anthropological Knowledge" (2004). Cornell Law Faculty Publications. Paper 996.

http://scholarship.law.cornell.edu/facpub/996

This Article is brought to you for free and open access by the Faculty Scholarship at Scholarship@Cornell Law: A Digital Repository. It has been accepted for inclusion in Cornell Law Faculty Publications by an authorized administrator of Scholarship@Cornell Law: A Digital Repository. For more information, please contact jmp8@cornell.edu. 
ANNELISE RILES

Cornell University

\section{Real time:}

\section{Unwinding technocratic and anthropological knowledge}

\section{A B S T R A C T}

"The Bank of Japan is our mother," bankers in Tokyo sometimes said of Japan's central bank. Drawing on this metaphor as an ethnographic resource, and on the example of central bankers who sought to unwind their own technocratic knowledge by replacing it with a real-time machine, I retrace the ethnographic task of unwinding technocratic knowledge from those anthropological knowledge practices that critique technocracy. In so doing, I draw attention to special methodological problems-involving the relationship between ethnography, analysis, and reception-in the representation and critique of contemporary knowledge practices. [risk, finance, economics, regulation, bureaucracy, expert knowledge, Japan]
7 the n his classic midcentury critique of U.S. politics, Theodore Roszak assails the technocracy as "that society in which those who govern justify themselves by appeal to technical experts who, in turn, justify themselves by appeal to scientific forms of knowledge. And beyond the authority of science there is no appeal" (1969:8). Like other theorists of his time (e.g., Meynaud 1969), Roszak follows Hannah Arendt (1976), Herbert Marcuse (1964), and Max Weber (Weber and Eisenstadt 1968) to focus on the way technocratic power is "the product of knowledge and extraordinary performance" (Winner 1977:139). Recent work revives this tradition to show, for example, how the assumptions and inner workings of bureaucratic knowledge impede citizen participation (Espeland 1994; Fischer 1990).

The location of the critique of technocratic power in the categories of bureaucratic knowledge has a long-standing and diverse theoretical pedigree. Michel Foucault (1991:92), for example, has shown how the conceptualization of the knowledge practices of government as distinct from an entity known as "economy” is an emblem of modern governmentality. Paul Rabinow (1989) and Frank Fischer (1990) describe technocracy in terms of particular practices of reason. From a different political point of view, the defender of free markets F. A. Hayek decried bureaucratic planning as the instantiation of the engineer mentality of the technocrat who believes he has "complete control of the particular little world with which he is concerned ... a man whose supreme ambition is to turn the world round him into an enormous machine" (1975:101-102).

For both Hayek and Foucault, the power of the knowledge-based critique of technocracy lay in the identification of the limits of technocratic knowledge. Foucault, borrowing from Adam Smith, argued that the powerful mystery of the market as "invisible hand" was that it remained invisible to the planner as much as to the market participant (Gordon 1991:12). For Hayek, likewise, the repeated failure of bureaucratic planning was simply a case of the larger failure of economic theory. The mathematical abstraction of economic planning distorted the true complexity of the

American Ethnologist, Vol. 31, No. 3, pp. 392-405, ISSN 0094-0496. (C) 2004 by the American Anthropological Association. All rights reserved. Send requests for permission to reprint to: Rights and Permissions, University of California Press, Journals Division, 2000 Center Street, Suite 303, Berkeley, CA 94704-1223. 
market, and, hence, such planning could not possibly make accurate predictions about the future (Bockman and Eyal 2002). This was a fundamentally temporal problem: Bureaucrats were by definition analyzing events that had already transpired, and economic planning, therefore, was continually behind the real-time movements of the market (Hayek 1952). In much the same way, contemporary critics have been particularly interested in the limitations of technocratic knowledge (Latour 1996; Mitchell 2002). Students of risk, for example, critique the efforts of scientists and planners to quantify, regulate, or plan around the unplannable (Beck 1992; Giddens 1991). ${ }^{1}$ Ethnographic studies document the points at which bureaucracy's targets of intervention lose faith in, and fashion responses to, ideals of technocratic knowledge such as "transparency" (West and Sanders 2003).

Ethnographers of technocracy have emphasized the way these very failures, however, become the engine of more technocracy - the way these failures create "gaps in the form" (Riles 2000:161) that serve as further "targets for intervention" (Castel 1991:288). James Ferguson points out that failure is the norm rather than the exception in development projects but that the failures of development, in turn, have their own productive effects: "Alongside the institutional effect of expanding bureaucratic state power is the conceptual or ideological effect of depoliticizing both poverty and the state" (1990:256). Science and technology studies (STS) scholars have technologically extended this last point to demonstrate how bureaucrats overcome conceptual limits by inventing devices that do the work of technocracy. Bruno Latour (1996), for example, has described Aramis, a transportation system for the city of Paris developed by French technocrats, as a continuation of bureaucratic politics by other means. Fabian Muniesa (2000b) describes a technology similar to the one at issue in this article-an automated "robot" built to match trades at the Paris stock exchange-as "moral architecture" developed to do what planning could not: root out corruption in trading. Muniesa goes on to show how, in the end, the robot's algorithmic principles in many respects reproduced both the inequities in the trading system and the knowledge practices of the bureaucrats who sought to regulate them.

The bureaucrats who are the subject of this article are officials at the Bank of Japan, Japan's central bank, and are responsible for the payment system by which funds move from one bank account to another in the economy; as such, they would seem to be archetypal producers of technocratic knowledge in this sense. Weber (1966:325) himself identified central bankers' manipulation of procedural policies, such as the workings of the payment system, as examples of bureaucratic "domination." Faith in technocracy and careful attention to its calibration are hallmarks of Japanese politics in the 20th century (Dimock
1968; Koschmann 2002; Morris-Suzuki 1994; Okimoto 1989; Tobioka 1993; Traweek 1999; Tsutsui 1998). Moreover, recent journalistic accounts of Japanese bureaucracy are full of the very critiques of technocratic knowledge practices now prevalent in the anthropology of technocracy. One recent volume, for example, asserts that "power in Japan is masked" (Mikuni and Murphy 2002:38) and emphasizes that the failures of Japanese bureaucracy are the product of a culturally specific but, ultimately, misguided faith in bureaucracy. ${ }^{2}$

More importantly, in the aftermath of the Asian financial crisis of the late 1990s and the consciousness of so-called systemic risk it amplified, the failures of technocratic knowledge that anthropologists and social theorists identify were very much at the forefront of these technocrats' own minds. In the face of both the inability of sophisticated economic models to predict economic crisis or provide solutions to recent market problems (Eisenbeis 1997) and current efforts by global banks to privatize the payment system and, hence, to do away with bureaucratic regulation altogether (American Banker 1997), these central bankers were fearful of their own powerlessness vis-à-vis the market they were expected to manage. As I will describe, these technocrats resolved this crisis, in their own conception, by creating a "real-time" machine that, they imagined, would obviate the need for planning altogether.

The critical anthropological vision of technocracy as a particular knowledge practice that inherently faces its own limits elucidates much about the character of the particular technocracy I will describe. Indeed, as I will suggest, this thesis replicates and amplifies a discourse about bureaucracy often heard among these technocrats themselves. The aim of this article, therefore, is not to dispute this insight but to point to other aspects of technocratic practice that become impervious to ethnographic analysis when one begins from this point of view. Specifically, by focusing on the content or categories of bureaucratic knowledge, these critiques obscure the question of how something comes to count as "knowledge" or as "not knowledge" in the first place. This, in turn, has consequences for the critical project: By accepting technocrats' claims that a (conceptual or mechanical) tool is a tool and by proceeding to inquire what kind of tool is at issue and what its effects might be, anthropologists commit themselves to a critique of technocratic knowledge premised on showing the artificial, determinate, and situated nature of seemingly transparent and universal categories such as "economy" that, as Timothy Mitchell points out, "leaves the world intact. Intentionally or not, it depends upon maintaining the absolute difference between representations and the world they represent" (2002:4).

To address this ethnographic limitation will require more than simply filling in the gaps in the ethnographic 
record: As I will suggest in the conclusion, to take on these matters will require attention to the points of affinity between technocratic and social scientific knowledge practices that provide the ground for premises about the nature of knowledge that are shared between anthropologist and technocrat. It will require unwinding the terms and practices of technocratic knowledge (anthropological and bureaucratic), I suggest. And, here, the efforts of the bureaucrats I describe to unwind their own technocratic practices may provide something of a model.

\section{Technocracy in crisis}

By the time of my fieldwork in the late 1990s, Japanese technocracy was by all accounts a practice in crisis. After almost ten years of economic recession, the media, the academy, and the public at large were losing faith in the utopian promises of technocracy. ${ }^{3}$ Most importantly, bureaucrats had their own doubts about their ability to plan. What exactly was the source of these planners' disquiet about technocracy-what had failed, from bureaucrats' point of view? A look at the perceived failures of one technocratic project, the design of the Japanese payment system, offers some insights.

Payment systems are sociotechnical achievements of the first order (Millo et al. 2003). Administered by central bankers in each country, they are the digital, legal, and institutional apparatuses by which money is actually transferred from one bank account to another. Every day, banks transfer through the Japanese payment system 300 trillion yen (approximately $\$ 2.5$ trillion) in approximately 20,000 transactions that represent the aggregate of millions of individual orders (Bank of Japan 2003). They do this by instructing the Bank of Japan's payment systems group to debit or credit the accounts they hold with the central bank's electronic clearing system, known as BOJ NET (Figure 1). ${ }^{4}$ At the time of my fieldwork, the Bank of Japan's Payment Systems Division was headed by a bureaucrat in his late forties, a graduate of the University of Tokyo and Harvard's Kennedy School of Government, whom I will call Sato.

Bureaucrats like Sato commanded considerable prestige and respect (Koh 1989; McVeigh 1998), although they were also the targets of jealousy and resentment of their social privilege. Almost all were graduates of the best Japanese universities' departments of law or economics and had scored high on a grueling civil service exam. Most of the bureaucrats I knew were ardently, if paternalistically, devoted to the mission of improving welfare by carefully managing the economy. They believed in their own intellectual capacities and technical skills, and they also shared a sense of responsibility for the consequences of their mistakes. Most of the bureaucrats I knew confessed a certain Keynesian ambivalence about the market's tenden-

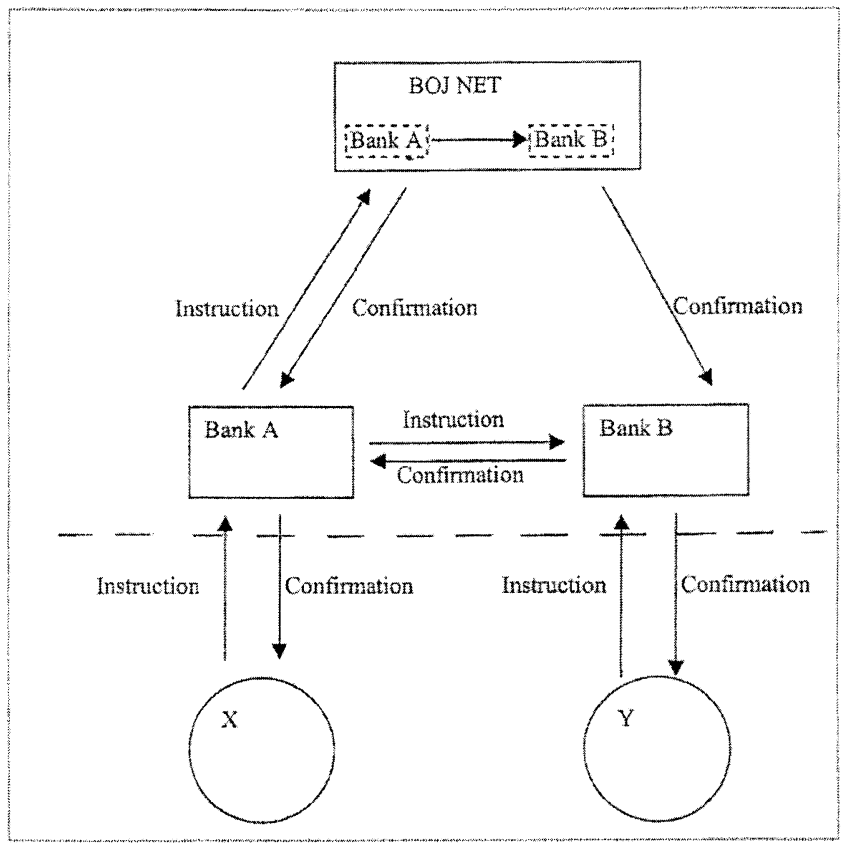

Figure 1. Schematic depiction of the clearing mechanism for a transfer of funds between customers $\mathrm{X}$ and $\mathrm{Y}$.

cy toward self-destabilization and, hence, believed in the need for intervention, at the margins, through planning. ${ }^{5}$ They also were painfully aware of the limits of their actual authority over market participants (Haley 1987).

The Payment Systems Division staff recently had become anxiously aware of a new concern: systemic risk. At the time of my fieldwork, BOJ NET was a so-called designated time net settlement system (hereafter, Designated Time). Banks accumulated obligations to one another throughout the day and, then, at a designated time each day, calculated the balance of who owed what to whom. This netting mechanism, engineered by the Payment Systems Division, was perceived by its architects as a small technocratic triumph, an example of the contributions of planning to the smooth functioning of the market (Kaufman 1996:826). Planners reasoned that it made little sense for Bank A to raise the funds to pay Bank B one billion yen at 10:00 a.m., for example, if Bank $B$ needed to pay Bank A two billion yen in a separate transaction at 2:00 p.m. the same day. The central bankers therefore had laboriously worked out the details of a system by which banks extended each other credit throughout the day and settled all their transactions at once, at a designated time. In this sense, Designated Time was a common example of technocratic progress through conceptual and institutional systemic integration: To its engineers, Designated Time was a conceptually sophisticated system because it was premised on the understanding that net balances were functionally equivalent to the sum total of individual transactions. In institutional terms, 
also, it represented bureaucrat-led coordination in the service of the common good.

As they contemplated their Designated Time system, however, these planners noticed that the very interconnectedness they had so carefully engineered created a new danger of its own: If one bank was unable to meet its obligations to pay others at the designated time, this, in turn, could leave others without the cash to meet their own obligations, and, hence, create a "domino effect" (Folkerts-Landau et al. 1996:1) that would lead to systemic failure (Bank of Japan 1996). Although systemic risk indexed bureaucratic failure, its very discovery was in itself a kind of technocratic achievement, from the planners' point of view. It could only be detected through careful contemplation of their system as an integrated and objectified whole (Douglas and Wildavsky 1982; Riles 2000; Stinchcombe 2001). They would not expect market participants, who, in their view, did not think about the market in systemic terms, to have an adequate appreciation of systemic risk.

I mentioned earlier that anthropologists and social theorists who point to the limits of technocracy most often locate these limits in the particular substance and character of technocratic knowledge. It is a view that the bureaucrats I knew largely shared. These bureaucrats often described themselves and their place in the market in terms of the special qualities of their knowledge. In particular, as they went about recalibrating the market, planners imagined two sides (Strathern 1988). On one side, bureaucrats, but also academics and some prominent lawyers and executives, created and maintained systems through planning. ${ }^{6}$ These persons were proximate outsiders, in bureaucrats' own conception. They worked at the threshold of the market they enabled and protected, looking in. On the other side, actual market participants acted within the market but did not think about it in systemic terms (Cetina and Bruegger 2002; Miyazaki 2003). Who was a market participant and who was a builder of the market varied situationally. At one moment, a bank executive might epitomize the market participant, whereas at another moment he (all such executives I knew were men) might be imaged as an institution builder. In this fairly rigid and formalistic sociological view, therefore, what differentiated the two sides was the character of their knowledge.

Moreover, if for Hayek as for Foucault, the failures of technocracy reflected the limits of economic reason, then, for these bureaucrats, systemic risk drew attention to the same. At the time of my fieldwork, central bankers in Japan and elsewhere were coming to view systemic risk as ultimately incalculable in economic terms. The problem was not simply computational complexity; some of the risks involved-uncertainty about what law might apply to a particular bank failure or how that law would be interpreted, for example-were altogether outside the realm of what could be quantified, in these technocrats' view. Like Hayek, they struggled with the temporal incongruity between the retrospective methods of positivist science and the prospective demands of the market (Hayek 1952; cf. Miyazaki 2003). As another payment systems expert, Robert Eisenbeis, director of research at the American Federal Reserve in Atlanta, put it, "Systems, instruments, and markets are evolving faster than the political entities can bring their various rules and regulations into harmony" (1997:50).

Yet bureaucrats' own claims for or against their knowledge practices notwithstanding, this focus on the inner workings of economic knowledge does not fully capture the character of the crisis of planning these bureaucrats confronted. For the bureaucrats I knew, two other kinds of problems complemented and even superseded problems of economic calculability. The first of these was in a sense a product of the very sociological thinking about the market that these bureaucrats embraced. In the last five years, bureaucrats had come under repeated attack from domestic and foreign media, politicians, and academics for failing to maintain the proper bureaucratic distance from the market-for muddying the logic of two sides. Ideological calls for "freeing the invisible hand" charged that Japanese bureaucrats were coddling the banks, stepping in to save them from bankruptcy when market logic demanded that they be left to fail (Porter and Takeuchi 1999:77). Hence, the banks did not internalize the costs of their inefficient behavior, and they did not take seriously the Central Bank's own threats to impose so-called market discipline-its threats to refuse to intervene in moments of crisis. The point here was not so much the weaknesses of economic knowledge as the personal weaknesses of the technocrat-his excessive intimacy with the market and his inability to control his own urge for benevolent intervention.

And there was another source to the crisis. As numerous observers have commented, Japanese bureaucrats maintain elaborate contacts with their classmates working in the industries they regulate (Schaede 1995). ${ }^{7}$ At the Bank of Japan, these relations were actively promoted through research fellowships for employees of major banks to spend a year working at the central bank, through informal study groups of bureaucrats, lawyers, and academics of roughly the same age, and through more formal committees of bureaucrats, academics, and representatives of industry (shingikai). Bank officials went to elaborate ends to cultivate these relationships: Senior bank staff told me that one of the purposes of sending young employees to pursue advanced degrees at elite institutions overseas was to give them an opportunity to develop close friendships with other Japanese of their own age. In the late 1990s, however, a number of corruption scandals focused on 
bureaucrats' practice of drinking and dining with their clients. What was at stake were bureaucrats' personal relations. Young bureaucrats I knew roundly criticized their seniors for what they saw as an outdated style of governance, the opposite of rationality (cf. Kelly 1986). At the end of an evening at a local restaurant, after dividing the bill with me down to the last yen and then requesting a receipt demonstrating that she had done so, Shimizu, a Bank of Japan employee in her early thirties, attacked what she termed the "arrogance and hegemonic behavior" of those who turned bureaucratic problems into personal relations and vice versa. Their error, she explained, was their failure to "keep things objective." Accepting entertainment from clients represented a deviation from proper bureaucratic practice, that is, the procurement and dissemination of knowledge on a rational basis.

If Shimizu's critique cast corruption in knowledge terms - as a problem of rationality and objectivity-those bureaucrats who sought to defend themselves against charges of corruption also cast their relationships with market participants as instrumental to bureaucratic knowledge. Central bankers regularly "made use" of personal friendships to "collect information," I was repeatedly told (Murakami and Rohlen 1987). Their task depended on-indeed, principally consisted in-gathering and dispersing information, on knowing the intimate details of what was happening within each institution, before it happened, and on coordinating a solution before problems mushroomed out of control, they lamented (Pempel and Muramatsu 1995:68). Often, these bureaucrats defended their actions in terms of neoclassical economic theories of market knowledge in which, because the market immediately absorbs knowledge into price, knowledge that is publicly held is, by definition, already worthless. If they waited to address the market's problems until everything had become publicly known and stock prices had plummeted, they would surely be blamed for failing to act quickly enough, they lamented.

Yet the instrumental rubric of knowledge acquisition at work in both the critiques of corruption and the defenses of bureaucratic relations did not do justice to the character of these relationships, as I observed them. First, political scientists and legal scholars have repeatedly noted that relationships between Japanese bureaucrats and their clients serve another instrumental purpose: Where the legal authority of Japanese bureaucrats to impose their policies is weak, personal obligation often substitutes for legal obligation (Haley 1987). But what is also not accounted for in this alternative instrumental explanation is the pleasure bureaucrats derived from friendship. Encounters between bureaucrats and clients proceeded according to a pattern. During the day, the two sides held formal encounters on government premises. ${ }^{8}$ Sometimes these meetings took place in front of the division manager, who sat at his desk pretending to read the newspaper as his junior carefully executed the interview. Usually on the night of the meeting, however, the clients would treat the junior bureaucrat to dinner (with his superior's tacit knowledge and approval), and after several rounds of drinks and conversation about a standard set of light topics, the conversation would turn back to the matter of that day (cf. Allison 1994). Both sides would take pleasure in breaking through the boundaries of formality they had created for themselves earlier and in "speaking in a straightforward way." Promises would be made that would serve as the basis of later action.

In response to the new discourse of accountability in the press and among bureaucrats themselves (Gupta 1995; cf. Jean-Klein 2002), the Bank of Japan had instituted a new policy: Henceforth, every meeting with clients would have to be cleared in advance with a manager and documented after the fact. The ironic effect of this policy was to place me as an ethnographer truly in the position of the participant-observer, because the difficulties I would encounter in maintaining relations with and seeking information from bureaucrats as a result of this policy were much like the difficulties they encountered every day in their relations with their clients. We shared a kind of technocratic crisis: Senior staff in particular complained of paralysis. Contacting market participants was the heart of what bureaucrats do, they began to claim (Holmes and Marcus in press). Yet, under the new policy, contacts with market participants were limited to office meetings that produced formulaic answers to predetermined questions and in which the parties did not feel free to make quiet requests for favors or compromises. Failure was built into technocratic practice insofar as the very technology of bureaucratic action was the subversion of formality (cf. Valverde 2003), of autonomy, and of the sociology of two sides. This is what one senior bureaucrat meant when he lamented that "we don't know anything about the market anymore."

It was in this context of failure, apprehended as a failure of knowledge, that, at the time of my fieldwork, the Payment Systems Division staff were planning to change their system entirely. Unlike the old Designated Time system, the new system, known as Real Time Gross Settlement (RTGS; hereafter, Real Time), proposed to settle each transaction individually and in full, in real time, that is, at the very moment an order to transfer funds was given (Bank of Japan 1998). ${ }^{9}$

As I noted earlier, ethnographies of bureaucracy, from anthropology to science studies, would predict that the payment system staff's discovery of systemic risk in the Designated Time system, and the wider crises of bureaucratic knowledge of which it was a part, would serve as an invitation to further planning projects, to building new systems. And, indeed, as a result of the discovery of 
systemic risk, division staff members were busy solving technical glitches, training market participants, testing their systems, and devising policies to handle contingencies as they had so many times before. Moreover, if, as Hayek suggests, planning was conceived as inherently one step behind the movements of the market, the sheer fact of moving to real-time transactions projected an aura of technocratic progress (cf. Weston 2002). Staff members also were fond of reminding me that Real Time constituted progress along another axis as well. Sato had first learned about Real Time at global conferences of central bankers from around the world. The move to Real Time was a "global trend" among central bankers (Johnson 1998; Kodres 1996), he emphasized, a small but crucial step toward ever greater international "harmonization" (cf. Drucker 1998). ${ }^{10}$

Indeed, using terms very close to those of science studies scholars, these bureaucrats talked of Real Time as a kind of step forward born out of the discovery of failure, that is, as a machine that synthesized law and technology to solve political problems surrounding the limits of economic knowledge. Real Time was, for them, a hybrid artifact. It demanded complex computer networks and programs, and one team within the division devoted itself to such issues as improving the speed of data transfer and creating backup systems. But it also demanded new laws and regulations, new policies, and new norms. Sato's ultimate objective was to write into the very architecture of the machine these standards of good market practice (Muniesa 2000a).

Yet if bureaucrats presented Real Time as just another technocratic advance, on closer examination, there was something puzzling about it from this point of view. This was most apparent in the opposition Real Time generated among economists and market participants: Employees of the banks that used the payment system, who by now had come to see how Designated Time saved them money, complained loudly that it would be far more costly to clear their transactions individually, in real time, because they would have to raise funds to meet each individual payment throughout the day. Economists, likewise, insisted that Designated Time was by far the wiser system because it saved money and avoided delays (Angelini 1998; Kahn and Roberds 1998; VanHoose 1991). By settling each transaction in the "now" of Real Time, in other words, Real Time replaced the very systemic knowledge that was the hallmark of economic and technocratic intervention, and to which market participants by now had learned to submit, with millions of discrete and individualized units of rights and obligations.

Real Time was not so much a new machine, therefore, as the unwinding of systemic knowledge, a return to how things had been prior to technocratic interventions that had produced Designated Time in the first place. In practice, Real Time was more like a fuse box than a supercomputer: Henceforth, it would not be necessary to plan for systemic crises in the payment system because Real Time would keep each transaction separate and, hence, prevent risk from spreading like falling dominoes through the system. Like the bank's policy on contact with outsiders, in other words, Real Time represented a defensive strategy-it responded to bureaucrats' own doubts about their ability to plan for the market by minimizing the consequences of market failure. But Real Time was also more perpetual motion machine than lever (Crook n.d.): By giving up the system, the central bank was also giving up one of its important means of intervention in the economy (Sato 1998). Hence, there would be neither the need for nor the tools of technocratic intervention.

Real Time therefore did not so much solve a problem of knowledge or continue politics by other means as express a particular kind of agency and respond to a particular desire-a "peculiar sort of modesty" premised on "self-invisibility" (Haraway 1997:32), a desire for an endpoint to knowledge itself (Miyazaki and Riles in press). In this respect, Sato enthusiastically encouraged market participants to develop private solutions to clearing that would decrease their reliance on the central bank altogether. "Sometimes [market participants] say these issues should not be fixed as a market practice but through guidelines from the Bank of Japan, but we refuse. We say, we're going to prepare a very flat table. And what kinds of plates and saucers you put on it is your own work," he told me.

Yet what most clearly defined Real Time as an endpoint to technocratic knowledge was what would happen to social relations under the new system. Ultimately, it was the impact of Real Time on the character of social relations that most interested Sato. He excitedly described how Real Time would encourage "self-responsibility" among market participants by requiring each to post collateral for the full value of his transactions in advance. Sato reflected in vivid detail to me about how, under Designated Time, bankers could just sit in their offices smoking away until the time of settlement each day. Under the new system, however, every second would count, and bankers would be forced to become far more alert, efficient, and nimble in their thinking. The initial chaos of Real Time, Sato argued, would eventually give way to a deeper level of order guided by "market practice." The difference would be that this new order would emerge on its own, from the aggregation of the actions of individuals, rather than as an artifact of his and others' planning. Social relations would cease to be tools, in other words, and become objects in the market, defined precisely by the way they were not a target of technocratic intervention. It is difficult to imagine a more powerful fantasy of the abdication of technocratic knowledge than this image of turning one's own tools into their 
very opposite, an object in the market, on which one chooses not to act.

So far, I have shown that, like anthropologists of technocracy, these technocrats readily asserted that failures or faults of technocratic knowledge provided the impetus for further technocratic knowledge projects. In these technocrats' ideological vision, knowledge was additive-knowledge (and its failures) begat more knowledge. Yet I have emphasized how these knowledge claims occluded a number of other dimensions of technocratic practice. First, social relations, imagined as something outside of and beyond knowledge, served, in bureaucrats' own view, as the very engine of technocratic knowledge and also its demise. But, second, even this notion of the social occluded something else-friendship, valued for its own sake as well as for the way personal relations generated information. And, third, I have sought to draw attention to another technocratic fantasy that exists alongside the fantasy of additive knowledge, like a kind of undertow-the fantasy of the endpoint to technocracy, of abdication of authority, of unwinding. The first step in my argument, therefore, is to suggest that ethnographers of technocracy take the moment of technocratic unwinding as seriously as they take moments of technocratic building and expansion.

\section{Needs}

Despite all the anxiety, the paralysis, and the fantasy of unwinding knowledge and relations I have described, Sato surprised me one day, after we had talked of the technicalities of Real Time over many weeks, when he told me that he ultimately expected the relationship between the Bank of Japan and market participants to change very little. "We decided to let the market participants go where they like," he said, "but we think they will make the right choices, they will settle in an acceptable zone." To my suggestion that once cut loose, the banks might go too far-they might, for example, develop their own private clearing system that would eliminate the need for the central bank altogether-Sato responded with skepticism. He could always create incentives for them to come back to the clearing system. And if nothing else, market participants would clear through the central bank some of the time because they needed banknotes.

A need for banknotes? The reference to concrete, physical money was shocking to me in a world of electronic transfers and numbers on balance sheets. In fact, it was the first time in the course of my fieldwork that I had been made aware of how paper money entered the system of electronic accounts. No one had ever discussed it, and I had not thought about it. Paper money had been invisible from the point of view of the technocrats' knowledge practices and my own.
Slowly I became aware of other such artifacts of the unwinding of technocratic knowledge. As planning for Real Time reached its final stages, an executive of one of Japan's largest banks worried that "the biggest problem of all is the central bank's role-to provide liquidity during the daytime." What emerged, for him, from the purposeful unwinding of technocracy into Real Time that I have described was a need: In the years of Designated Time, banks had relied on the fact that they did not need funds to settle their transactions until the end of the day, and the number of transactions had increased exponentially. Yet, if every transaction henceforth had to be settled on the spot, banks needed liquidity—cash—to meet their obligations in real time. The effect of Real Time for bankers like this executive, then, was a move from an awareness of system and systemic risk to an awareness of liquidity-a move from knowledge of systems to something of a different order, needs. The Payment Systems Division staff likewise repeatedly drew my attention to these needs. One team member even hastily sketched out a powerful image that emphatically articulates needs in the form of negative balances that member banks would incur in their accounts with the Bank of Japan between the hours of 9 a.m. and 5 p.m. each day (Figure 2).

This conversion of risks into needs is not outside the technocratic vocabulary of planning and systems I have described. Traditional philosophical justifications for the welfare state and its planning, for example, are grounded in the satisfaction of individual and social needs (Walzer 1984). In fact, it is possible to understand the larger technocratic vocabulary of risk management that Real

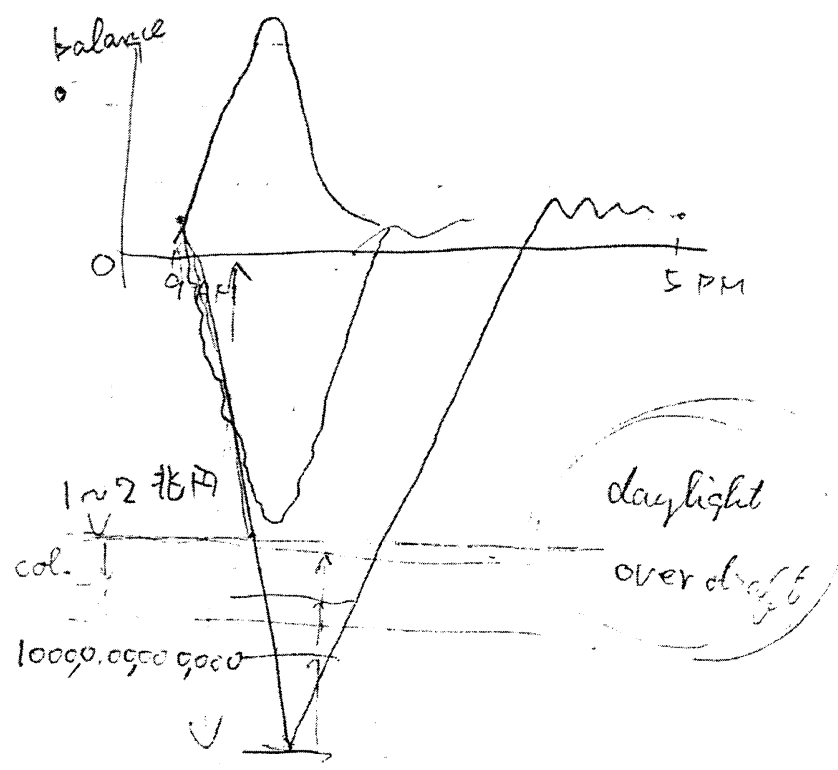

Figure 2. Drawing produced by a Payment Systems Division official during the course of a conversation about Real Time with me. 
Time deployed as heir to an earlier, equally technocratic vocabulary of (social) needs (Mariana Valverde, personal communication June 24, 2002). In the academic context, likewise, Marshall Sahlins (1996) has shown, with respect to both anthropological functionalism and neoclassical economic analysis, that the corollary to social scientists' fascination with self-perpetuating systems is a notion of needs as "pure materiality," something outside the system that renders it eternally necessary, as when society is a function of biological needs or markets are a function of needs for liquidity. I want to suggest, therefore, that anthropologists think of systems and needs as a kind of pair. But what is important is that, unlike knowledge and social relations or bureaucracy and corruption, this particular pair is not immediately apprehensible as such by its users (technocrat or academic). Needs are not a "subject" in the anthropology of bureaucracy, for example. My ethnographic claim, in other words, is that the notion of "needs" works as a counterpart to technocratic knowledge that is readily available within the technocratic idiom and yet not immediately apprehensible as such.

Once needs become visible ethnographically as a technocratic resource, it will be apparent to readers that their emergence at this moment of unwinding technocratic knowledge, in turn, created a new technocratic opportunity. In particular, from the point of view of needs for liquidity, Real Time represented a reassertion of technocratic authority in a different guise. The movement to Real Time was a movement from an older system of interdependence, in which the banks extended credit to one another, to a system in which each bank became individually dependent on the central bank alone to fulfill its intraday credit needs. "We are prepared to supply intraday overdraft to support RTGS," Sato told me with a mixture of gravity and triumph, as I voiced market participants' concern about the need for liquidity. The Bank of Japan would loan funds to the users of its payment systemallow them to keep negative balances until the end of the day - so that they could meet their obligations in real time. But this was easier said than done. As the bank executive quoted above told me, "[The central bank] has 3 trillion yen in all the accounts put together. But 30 trillion yen is needed to keep this system going." In other words, the banks' needs for liquidity also highlighted the Bank of Japan's own needs-and the difficulties it would have meeting the needs of its charges. The Bank of Japan emerged as a silent provider of needs that drew its strength from a kind of explicit weakness and from the performance of the awesome feat of providing the impossible but acutely necessary at the moment of need. ${ }^{11}$

But if it is possible to see provision for needs as the continuation of technocratic politics by other means, in much the same way that STS scholars have shown bureaucratic technologies to be, it is important to take note of how this was accomplished. It was not the content of technocratic knowledge that did the work here, as critics of technocracy, from Foucault to Hayek, would suggest, but, rather, the stopping and unwinding of technocratic knowledge and its replacement by a kind of action (the provision for needs) recognizable from inside the practice of technocracy but occluded from technocrats' view by their own knowledge-based claims. This unwinding was possible because of the particular features of needs as entities already inside the sphere of technocratic practice but also outside, utterly unrelated, irrelevant to technocratic knowledge-pure materiality, as Sahlins puts it. That is, the problem of needs obviated all earlier concerns and anxieties surrounding the logic of two sides, for bureaucrats as for politicians, market participants, and journalistic and academic observers alike-it simply fell outside the scope of representational practice. ${ }^{12}$ Unlike the technocrats' transformation of social relations into knowledge, the transformation of risk into needs did not yield an object of contemplation or critique. I never heard people like Shimizu, the bank employee who critiqued her superiors' indulgence in social relations, make an issue of needs, for example. And Sato's efforts to provide liquidity did not pose a contradiction, in his own mind, with his commitment to maintaining the proper bureaucratic distance from the market. In other words, the power of needs as technocratic practice was that it was not particularly perceptible as technocratic strategy to technocrats themselves. I surmise that it is precisely because the logic of needs is so much of a piece with the logic of systemsbecause needs are so intimate to knowledge-that they became available as a site at which technocratic knowledge itself disappeared.

\section{Unwinding anthropological knowledge}

As I have presented it here, this insight about the work that is done by moving from what registers as knowledge to what does not count as knowledge, from technocrats' point of view, seems straightforward. But it highlights a simple but intractable problem for critics who focus on the nature of technocratic knowledge: The very knowledge practice that would seek to identify the politics of technocracy in this case is incapable of doing so-because that politics works precisely by virtue of its existence beyond knowledge, for the technocrat as for technocracy's critic. To address the problem requires confronting the ways in which anthropology is of a piece with its object of critique, technocratic knowledge. The ethnographic moment when I, personally, could resist this insight no longer came when Sato himself admonished me, as a researcher, to pay particular attention to "the location of power in the market." Another marker of this problem is the way, as mentioned at the outset, that the critiques of the power of 
technocracy are already anticipated and elaborated by journalists and even by technocrats themselves.

In drawing attention to this problem, I build on a growing body of work that emphasizes the parallels between technocratic and anthropological or social scientific knowledge. Holmes and Marcus describe the knowledge practices of central bankers as "paraethnographic" to emphasize that the "informants of ethnography must be rethought as counterparts rather than 'others' " (in press). Carol Greenhouse and Marilyn Strathern point to the ways categories, such as "state" (Greenhouse 2002) or "audit" (Strathern 2000), serve as analogs for anthropological categories, such as "society" or "culture." Bill Maurer (2002) and I (Riles 2000) have emphasized parallels at the level of form between anthropological and technocratic knowledge practices. Frank Fischer (1990:16-17) and Nigel Thrift (1996:12), in different ways, highlight the shared positivist assumptions of technocracy and its critics. Technocracy in this body of work emerges as a point at which anthropological representations and the world they represent come together in certain shared practices of knowledge.

But what interests me here is the particular problem this condition poses for ethnography and for critical work. How can anthropologists, who work within the same intellectual traditions as the technocrats I have described, apprehend precisely that which garners its power from its inaccessibility to technocratic knowledge? Here is where anthropologists need some unwinding of our own knowledge from the technocratic practices I have described: What was imperceptible to the technocrat was also imperceptible to the ethnographer.

I suggest that unwinding anthropological knowledge is first and foremost an ethnographic project, rather than an analytical one. The analytical work is straightforward and after the fact, the ethnographic work discouragingly difficult. In the example I have provided, the work of seeing the politics of Real Time lay in making needs available as a subject of ethnographic description. But once this ethnographic work was accomplished, the analysis of that subject looked so entirely obvious that it engendered a further problem of reception: Readers accustomed to straightforward presentations of data followed by baroque analytics will feel that the material is left unanalyzed. So, what is required to make evident the nature of unwinding, as anthropological practice, is a kind of violation of the aesthetics of anthropological representation-I need to retrace how the ethnographic work was done, to show how the unwinding took place.

In the course of my fieldwork, I sometimes encountered a jarring statement from the executives of the private banks that the Bank of Japan was charged with regulating: "The Bank of Japan is our mother." The phrase was in no sense pejorative or cynical; it was thrown out rather as a kind of shorthand, a way of giving me, the outside observer, a means of understanding what was going on. I never heard this metaphor used by central bankers themselves, and I suspect they would experience a certain amount of embarrassment at its discovery and elaboration by a foreign observer. Their quite legitimate fear, I imagine, would be that observers would once again read into such a metaphor a critique of their technocratic practices as distinctly "Japanese" and, hence, as somehow less than truly modern. Their fear would be that an anthropologist would deploy such a metaphor in the service of a culturalist analysis that would seek to explain Japanese technocracy as a product of the particular features of the Japanese cultural context. This is not at all my aim.

Instead, what was productive about this metaphor, or, rather, the experience of encountering it, was the way it made evident to the ethnographer certain baselines in Euro-American anthropological knowledge practices. ${ }^{13}$ It did not fit with my own assumptions about how to think about government and market. In his discussion of governmentality alluded to above, for example, Foucault contrasts modern technocratic knowledge with "pastoralism" - with a notion of the state as a father figure in which economy is "the correct manner of managing individuals, goods and wealth within the family" (1991:92). What would be elucidated about central bankers' practices by thinking about motherhood, I wondered? Prompted by this disjuncture, I began to conduct parallel fieldwork among mothers and sons in one upper-middle-class suburb of Tokyo, of the kind in where many of the bankers I met in the city had grown up or currently lived.

The ground for the metaphor, for my Japanese interlocutors, was a taken-for-granted notion of the household. As Chie Nakane (1967) argued in her classic critique of the application of structural functionalist kinship theory to Japanese society, the Japanese household is first and last an economic unit. The association of the household with finance is so strong that, in popular conversation, the word kitchen (daidokoro) serves as shorthand for a firm's financial condition (as in the question, "how are things in the kitchen?”). Since the Meiji period, official state ideology has asserted that mothers should serve as managers of the household economy, and, hence, motherhood is readily associated with economic productivity (Nolte and Hastings 1991:171-172) and financial expertise, such that men often refer to their wives as "our minister of finance" (uchi no okura daijin). In drawing together household and economy, therefore, my interlocutors did not relate two disparate domains. I imagine that they had no idea that what, from their point of view, was quite mundane phrasing was confusing to me.

At issue, also, was a particular understanding of the politics of motherhood. As sociologist and feminist theorist Ueno Chizuko (1994) has commented, the Japanese 
mother is the dominant figure in the household. Her dominance has emerged because and in spite of her structurally weak position since the postwar invention of the role of full-time wife and mother (Ueno 1988). ${ }^{14}$ As implied by the mildly derogatory phrase "education mommy" (kyouiku mama), the values at once cherished and feared in a mother are commitment, endurance, and single-mindedness about doing what it takes to see to the child's success in the competitive educational system (Allison 1996; Lebra 1984:192-208).$^{15}$ Ueno observes that in the Japanese family, the mother's authority is always receding, for, in encouraging her children to be different from and more successful than their father, she is also encouraging them to leave her behind. For the mothers and sons I knew, this awareness that the relationship must become attenuated over time was precisely what rendered it continually new and strong. Because a son spends most of his life pulling away, he, in effect, always remains close. According to the popular press, mothers' inability to give up their excessive concern for the affairs of their sons results in the weak character of adult men and is singled out as a social problem, the "mother complex" (mazakon). Hence, in referring to the Bank of Japan as "our mother," market participants most likely flagged the intimate involvement of the Bank of Japan in the problems of Japanese banks and the willingness of its staff to share in a very personal way in the burdens of Japanese financial institutions.

Yet, for these bankers, the metaphor also would have flagged power. Ueno's description of how the Japanese mother is able to carve from a position of structural weakness a kind of dominance within the household aptly captures the central bank's position in the Japanese market, as I have shown. Fieldwork drew my attention to the awesome power the mothers I knew derived within the household from their devotion to a managerial role imagined, as with Foucault's pastorialism, to concern economy in the widest and most intimate sense of personal and collective welfare and growth. The mother was, for middleaged, successful, and driven sons, an icon of intervention of a conflictual, moderately repulsive, and sometimes even violent, but ultimately unavoidable, kind.

In the practice of thinking about one ethnographic domain by working through another, I found further metaphorical possibilities of my own. In particular, the mothers and sons I knew were intimate in a way that was impervious to articulation. In fact, they seemed to go out of their way to avoid such articulation, to the point at times of expressing a certain degree of frustration at my fascination with mother-son relations. Mothers and sons I knew did not verbalize affection toward one another, as Euro-American mothers and children routinely feel compelled to do. Mothers seemed far more interested in the task of providing for concrete needs, such as assuring the proper combination of vegetables at dinner or a quiet place to study, than in giving explicit advice or making rules for their children (Kondo 1990). As they grew older, sons and mothers made constant demands on one another that went unnoticed, unaccounted for, by both sides. Whereas most kinds of social relations were carefully calibrated, always tricky to negotiate, mothers and sons of all ages tolerated a seemingly infinite amount of imposition and even hostility from one another. It would be impossible, in other words, to think of mothers and sons as two sides. Hence, their puzzling assertions to me, in light of the constant demands I observed, that they had no relationship at all.

The work this metaphor did for me as ethnographic practice, in other words, was to push me to think about what was not relations and, hence, not knowledge. In particular, it located a new ethnographic artifact-intimacy-a condition of oneness within which it is possible honestly to insist that no relationship exists, indeed, to experience and assert not connection but repulsion. It made visible a form of politics imperceptible with the current tools of political critique.

Mine is a simple, even impressionistic account of unwinding. But I offer it here to call for more serious attention to the work of ethnographic practice, as distinct from theory and analysis, in conditions of intimacy between anthropological knowledge and the knowledge practices, such as technocracy, that it seeks to represent. Indeed, to suggest that there are parallels between technocratic knowledge and anthropology's own knowledge practices would be far too weak a statement. I have been describing fieldwork in anthropologists' own categories: a sociological understanding of market, premised at an ideological level on the authority of science but ultimately fueled by a faith in social relations, and one that is increasingly attuned to its limits such that it entertains fantasies of its own unwinding. Here I can only account after the fact for how the jarring sensibility of a metaphor, drawn idiosyncratically from the material, served not as a means of elucidating a cultural truth but as a way of ethnographically unwinding the agreed bases of anthropological and planning knowledge that make the ethnography of technocracy so intractable in the first place.

Let me restate this another way. Materials like those presented here are very much a part of the anthropologist's world, and, yet, they are also highly exotic. Unlike the exoticism that fueled earlier generations of anthropology, however, payment systems do not seem to invite anthropological reflection. Like needs for the technocrats I have described, these technocratic practices hide themselves not by their strangeness but by denying the anthropologist the cues or hooks that engage the analytical imagination. They do not present themselves as another side to anthropology's own intellectual concerns. This is the hallmark of intimacy. 
As an ethnographic subject, therefore, technocracy raises questions about how a subject engages or remains inaccessible to the anthropological imagination in the first place. The example I have offered of the conversion of technocratic knowledge into the unnoticed, untheorized fulfillment of needs provides an apt metaphor for how subjects become invisible, inaccessible to analysis-by bureaucrats and anthropologists alike. My contribution to this problem has been to draw attention to two dimensions of anthropological practice other than representation or analysis - to the act of ethnographic unwinding and to the act of the reception of the anthropological text-that serve as resources at this juncture precisely because they are not technocratic-they are not common to anthropologists and their technocratic subjects. Rather, like needs for the technocrats I have described, these two dimensions are part of the task and yet invisible, occluded by our own analytical practices. Perhaps the moment is ripe for further unwindings of our own.

\section{Notes}

Acknowledgments. This article draws on 18 months of fieldwork among financial regulators in Tokyo conducted from August to September 1997, from September to November 1998, from August 1999 to July 2000, and from August to September 2001. I am grateful to the staff of the Payment Systems Division of the Bank of Japan for so generously sharing their time and knowledge with me. I also thank Masatoshi Okawa for his support of my project and for first drawing my attention to payment systems as a research topic. Research was funded by the American Bar Foundation. Writing was conducted under the auspices of the Howard Foundation, the American Council of Learned Societies, the National Endowment for the Humanities, and the Social Science Research Council. Earlier versions of this article were presented at the New York University Institute for Law and Society on November 13, 2000; the Society for Cultural Anthropology invited session "Theorizing Failure: An Example from the Anthropology of Finance" at the Annual Meeting of the American Anthropological Association, November 18, 2000; the American Bar Foundation, November 29, 2000; the Northwestern University Center of International and Comparative Studies, January 8, 2001; the University of California at Berkeley Department of Anthropology, January 18, 2001; the Center for Transcultural Studies Working Group on Global Imaginaries, March 25, 2001; the New York Conference on Social Studies of Finance held at Columbia University, May 3-4, 2001; the Feminism and Legal Theory Conference held at the University of Buffalo, April 20-21, 2001; the Cornell University Department of Science and Technology Studies Conference, April 12, 2003; and the Cornell University Social Sciences Seminar on Law, Norms, and Society, March 16, 2004. I thank the participants in these sessions for their criticisms, and Marianne Constable, Tony Crook, Bryant Garth, Carol Greenhouse, Jane Guyer, Laura Hein, Doug Holmes, Iris Jean-Klein, Amy Levine, George Marcus, Bill Maurer, Fabian Muniesa, Kunal Parker, Adam Reed, Marilyn Strathern, and Mariana Valverde for comments and assistance of many kinds. This article emerges from a larger collaborative project with Hiro Miyazaki, and I owe him a special debt for his assistance at every stage.
1. In a recent book, for example, Lee Clarke (1999) has drawn attention to what he describes as "fantasy documents"-institutional documents that ostensibly plan for unquantifiable risks or extraordinary disasters but whose real purpose is to serve as "rationality badges" that assure the institution, the public, and its various constituencies that, in the event of a certain disaster, the institution would know how to act.

2. Marilyn Ivy warns that anthropologists should be particularly suspicious of these ubiquitous critiques of Japanese culture and suggests that anthropologists understand these anxieties, rather, as statements about "the dialectically entwined status of the United States (as the paradigm of the West) and Japan as national-cultural imaginaries" (1995:3).

3. The U.S. bond-rating agency, Moody's, had even downgraded Japanese government bonds (JGB) in what bureaucrats took as a humiliating suggestion that the government itself was not entirely on sound financial footing (Dore 1999).

4. BOJ NET handles transfers of cash from the accounts of 916 member banks. It handles "wholesale" fund transfers (between banks on behalf of their individual clients or between participants in a special foreign exchange clearing system). In addition to cash, BOJ NET also handles transfers of JGBs.

5. Laura Hein (2003) has shown how, in the postwar period, Japanese intellectuals and bureaucrats have understood the technocratic manipulation of capitalist economic models as a progressive project associated with anti-imperialism (cf. Harootunian 2000:101). Tessa Morris-Suzuki (1994:163) describes how the ideology of a technocratic project in the service of militarism in prewar Japan was effortlessly converted into an ideology of technocracy in the service of democracy and economic growth in the postwar period and how the technocratic dimension of U.S. politics held particular appeal for Japanese elites. Likewise, in his exposition of debates among bureaucrats and their intellectual advisors in the prewar period, Vic Koschmann (2002) demonstrates that Japanese technocrats shared a concern with the "crisis of capitalism"- the disunities and imbalances it creates and the need to offset those imbalances through bureaucratic intervention.

6. Bank executives often serve as semipublic figures in Japan; they represent their industries on government committees and devote a considerable amount of their time to drafting regulations and working with bureaucrats on policy issues. In this role, they are expected to speak for their industry as a whole, rather than to represent the interests of their own institutions (although in practice their efforts often favor their own institutions' interests in subtle ways).

7. Until recently, Japanese bureaucrats usually retired to positions as titular heads of private corporations, from which they continued to serve as conduits between government and industry (Calder 1989).

8. Each bank and securities firm assigned particular employees the full-time responsibility of meeting regularly, both during the day and after work, with bureaucrats in each ministry that regulated their activities (cf. Schwartz 1998:187).

9. Real Time ultimately went into operation on January 4, 2001.

10. Real Time was first implemented by the U.S. Federal Reserve in the aftermath of the bank failures of the 1980s.

11. How the Payment Division staff solved this problem is a fascinating but highly technical story beyond the scope of this article.

12. In this respect, it is ethnographically significant, in my view, that the Real-Time system received no academic attention and practically no journalistic attention and was also ignored by the politicians who routinely critique the Japanese bureaucracy. 
13. I use the awkward phrase "Euro-American anthropological knowledge practices" to distinguish the work of Japanese anthropologists, which, in my opinion, does not always replicate the particular assumptions about knowledge and market at issue here.

14. Unlike in the ideology of the middle-class, Euro-American family defined by "horizontal intimacy founded on the romantic sexual intimacy of one man and one woman" (Fineman 1995:145), as Nakane puts it, "the structure of the [Japanese] family is based on a central core, mother and children, to which husband (father) attaches" (1970:132).

15. As Kathleen Uno (1999) has pointed out, this ideology of motherhood as complete devotion to the education of children obscures the variety of actual practices of motherhood in Japan, including, in particular, those of rural and working-class women (cf. Allison 1996:xiv). On the expectations of midcentury employers of "salary men" about the full-time devotion of their employees' wives to motherhood, see Rohlen 1974.

\section{References cited}

\section{Allison, Anne}

1994 Nightwork. Chicago: University of Chicago Press.

1996 Permitted and Prohibited Desires: Mothers, Comics, and Censorship in Japan. Boulder: Westview Press.

American Banker

1997 Is There a Private Global Central Bank in Your Future? The American Banker, May 12: 44-48.

Angelini, Paolo

1998 An Analysis of Competitive Externalities in Gross Settlement Systems. Journal of Banking and Finance 22:1-18.

Arendt, Hannah

1976 The Origins of Totalitarianism. New York: Harcourt Brace Jovanovich.

Bank of Japan

1996 Nihon Ginko touza yokin kessai no "RTGS-ka" ni tsuite (About the move to RTGS for the settlement of deposits at the Bank of Japan). Tokyo: Bank of Japan.

1998 The Framework for Restructuring BOJ-NET JGB Services. Tokyo: Bank of Japan.

2003 Payment and Settlement Statistics. Tokyo: Bank of Japan.

Beck, Ulrich

1992 Risk Society: Towards a New Modernity. Newbury Park, CA: Sage Publications.

Bockman, Johanna, and Gil Eyal

2002 Eastern Europe as a Laboratory of Economic Knowledge. American Journal of Sociology 108(2):310-352.

Calder, Kent E.

1989 Elites in an Equalizing Role: Ex-Bureaucrats as Coordinators and Intermediaries in the Japanese Government-Business Relationship. Comparative Politics 21(4):379-403.

Castel, Robert

1991 From Dangerousness to Risk. In The Foucault Effect: Studies in Governmentality: With Two Lectures by and an Interview with Michel Foucault. Graham Burchell, Colin Gordon, and Peter Miller, eds. Pp. 281-298. London: Harvester Wheatsheaf.

Cetina, Karen Knorr, and Urs Bruegger

2002 Traders' Engagement with Markets: A Postsocial Relationship. Theory, Culture and Society 19(5-6):161-185.

Clarke, Lee

1999 Mission Improbable: Using Fantasy Documents to Tame Disaster. Chicago: University of Chicago Press.

Crook, Tony

N.d. Transactions in Perpetual Motion. Unpublished MS, Department of Social Anthropology, University of St. Andrews.
Dimock, Marshall Edward

1968 Japanese Technocracy: Management and Government in Japan. New York: J. Weatherhill.

Dore, Ronald

1999 Japan's Reform Debate: Patriotic Concern or Class Interest? Or Both? Journal of Japanese Studies 25(1):65-89.

Douglas, Mary, and Aaron B. Wildavsky

1982 Risk and Culture: An Essay on the Selection of Technical and Environmental Dangers. Berkeley: University of California Press.

Drucker, Peter

1998 In Defense of Japanese Bureaucracy. Foreign Affairs 77(5):68-80.

Eisenbeis, Robert A.

1997 International Settlements: A New Source of Systemic Risk? Federal Reserve Bank of Atlanta Economic Review (Second Quarter):44-50.

Espeland, Wendy

1994 Legally Mediated Identities: The National Environmental Policy Act and the Bureaucratic Construction of Interests. Law and Society Review 28(5):1149-1179.

Ferguson, James

1990 The Anti-Politics Machine: “Development," Depoliticization, and Bureaucratic Power in Lesotho. Cambridge: Cambridge University Press.

Fineman, Martha A.

1995 The Neutered Mother, the Sexual Family and Other Twentieth Century Tragedies. New York: Routledge.

Fischer, Frank

1990 Technocracy and the Politics of Expertise. Newbury Park, CA: Sage Publications.

Folkerts-Landau, David, Peter Garber, and Dirk Schoemaker

1996 The Reform of Wholesale Payment Systems and Its Impact on Financial Markets. Occasional Paper, 51. Washington, DC: Group of Thirty.

Foucault, Michel

1991 Governmentality. In The Foucault Effect: Studies in Governmentality: With Two Lectures by and an Interview with Michel Foucault. Graham Burchell, Colin Gordon, and Peter Miller, eds. Pp. 87-104. London: Harvester Wheatsheaf. Giddens, Anthony

1991 Modernity and Self-Identity: Self and Society in the Late Modern Age. Cambridge: Polity Press.

Gordon, Colin

1991 Government Rationality: An Introduction. In The Foucault Effect: Studies in Governmentality: With Two Lectures by and an Interview with Michel Foucault. Graham Burchell, Colin Gordon, and Peter Miller, eds. Pp. 1-51. London: Harvester Wheatsheaf.

Greenhouse, Carol J.

2002 Introduction: Altered States, Altered Lives. In Ethnography in Unstable Places: Everyday Lives in Contexts of Dramatic Political Change. Carol Greenhouse, Elizabeth Mertz, and Kay Warren, eds. Pp. 1-34. Durham, NC: Duke University Press.

Gupta, Akhil

1995 Blurred Boundaries: The Discourse of Corruption, the Culture of Politics, and the Imagined State. American Ethnologist 22(2):375-402.

Haley, John O.

1987 Governance by Negotiation: A Reappraisal of Bureaucratic Power in Japan. Journal of Japanese Studies 13(2):343-357.

Haraway, Donna Jeanne

1997 Modest_Witness@Second_Millennium.FemaleMan@ Meets_OncoMouse $^{\mathrm{TM}}$ : Feminism and Technoscience. New York: Routledge. 
Harootunian, Harry D.

2000 Overcome by Modernity: History, Culture, and Community in Interwar Japan. Princeton: Princeton University Press.

Hayek, F. A.

1952 The Counter-Revolution of Science. Glencoe, IL: Free Press.

1975 The Rule of Law. Menlo Park, CA: Institute for Humane Studies.

Hein, Laura

2003 Statistics for Democracy: Economics as Politics in Occupied Japan. Positions: East Asia Cultures Critique 11(3):765-778.

Holmes, Douglas R., and George E. Marcus

In press Cultures of Expertise and the Management of Globalization: Toward the Refunctioning of Ethnography. In Global Assemblages: Technology, Politics and Ethics as Anthropological Problems. Aihwa Ong and Stephen J. Collier, eds. Oxford: Blackwell.

Ivy, Marilyn

1995 Discourses of the Vanishing: Modernity, Phantasm, Japan. Chicago: University of Chicago Press.

Jean-Klein, Iris E. F.

2002 Alternative Modernities, or Accountable Modernities? The Palestinian Movement(s) and Political (Audit) Tourism during the First Intifada. Journal of Mediterranean Studies 12(1):43-80.

Johnson, Omotunde E. G.

1998 Payment Systems, Monetary Policy, and the Role of the Central Bank. Washington, DC: International Monetary Fund.

Kahn, Charles M., and William Roberds

1998 Federal Reserve Bank of Atlanta: Real-Time Gross Settlement and the Costs of Immediacy (Working Paper 98-21). Atlanta: Federal Reserve Bank of Atlanta.

Kaufman, George G.

1996 Comment by George G. Kaufman. Journal of Money, Credit, and Banking 28(4):825-831.

Kelly, William

1986 Rationalization and Nostalgia: Cultural Dynamics of New Middle-Class Japan. American Ethnologist 13(4):603-618.

Kodres, Laura E.

1996 Foreign Exchange Markets: Structure and Systemic Risks. Finance and Development 33(4):22.

Koh, B. C.

1989 Japan's Administrative Elite. Berkeley: University of California Press.

Kondo, D. K.

1990 Crafting Selves: Power, Gender and Discourses of Identity in a Japanese Workplace. Chicago: University of Chicago Press.

Koschmann, Victor J.

2002 Tekunorojii no shihai/shihai no tekunorojii [Rule by technology, technologies of rule]. In Sôryokusenka no chi to seido, 1935-55 [Iwanami kôza kindai Nihon no bunkashi 7]. Komori Yôichi et al., eds. Pp. 139-172. Tokyo: Iwanami Shoten.

Latour, Bruno

1996 Aramis, or, the Love of Technology. Cambridge, MA: Harvard University Press.

Lebra, Takie Sugiyama

1984 Japanese Women: Constraint and Fulfillment. Honolulu: University of Hawai'i Press.

Marcuse, Herbert

1964 One Dimensional Man: Studies in the Ideology of Advanced Industrial Society. Boston: Beacon Press.
Maurer, Bill

2002 Anthropological and Accounting Knowledge in Islamic Banking and Finance: Rethinking Critical Accounts. Journal of the Royal Anthropological Institute 8:645-667.

McVeigh, Brian J.

1998 The Nature of the Japanese State: Rationality and Rituality. London: Routledge.

Meynaud, Jean

1969 Technocracy. New York: Free Press.

Mikuni, Akio, and R. Taggart Murphy

2002 Japan's Policy Trap: Dollars, Deflation, and the Crisis of Japanese Finance. Washington, DC: Brookings Institution Press.

Millo, Yuval, Fabian Muniesa, Nikiforos S. Panourgias, and Susan V. Scott

2003 Detaching Trades: Clearing and Settlement as a Calculative Space. Paper presented at the Constance Conference on Social Studies of Finance. Constance, Switzerland, May $16-18$.

Mitchell, Timothy

2002 Rule of Experts: Egypt, Techno-Politics, Modernity. Berkeley: University of California Press.

Miyazaki, Hirokazu

2003 The Temporalities of the Market. American Anthropologist 105(2):255-265.

Miyazaki, Hirokazu, and Annelise Riles

In press Failure as an Endpoint. In Global Assemblages: Technology, Politics and Ethics as Anthropological Problems. Aihwa Ong and Stephen J. Collier, eds. Oxford: Blackwell Press.

Morris-Suzuki, Tessa

1994 The Technological Transformation of Japan: From the Seventeenth to the Twenty-First Century. Cambridge: Cambridge University Press.

Muniesa, Fabian

2000a Performing Prices: The Case of Price Discovery Automation in the Financial Markets. In Facts and Figures: Economic Representations and Practices. Herbert Kalthoff, Richard Rottenburg, and Hans-Jürgen Wagener, eds. Pp. 289-312. Economy and Society Yearbook 16.

2000b Un robot walrasien: Cotation électronique et justesse de la découverte des prix. Politix 13(52):121-154.

Murakami, Yasusuke, and Thomas P. Rohlen

1987 Social-Exchange Aspects of the Japanese Political Economy: Culture, Efficiency, and Change. In The Political Economy of Japan, vol. 3. Shumpei Kumon and Henry Rosovsky, eds. Pp. 63-105. Stanford: Stanford University Press.

Nakane, Chie

1967 Kinship and Economic Organization in Rural Japan. London: University of London Athlone Press.

1970 Japanese Society. Berkeley: University of California Press.

Nolte, Sharon H., and Sally Ann Hastings

1991 The Meiji State's Policy toward Women, 1890-1910. In Recreating Japanese Women, 1600-1945. Gail Lee Bernstein, ed. Pp. 151-198. Berkeley: University of California Press.

Okimoto, Daniel I.

1989 Between MITI and the Market: Japanese Industrial Policy for High Technology. Stanford: Stanford University Press.

Pempel, T. J., and Michio Muramatsu

1995 The Japanese Bureaucracy and Economic Development: Structuring a Proactive Civil Service. In The Japanese Civil Service and Economic Development: Catalysts for Change. H.-K. Kim, M. Muramatsu, T. J. Pempel, and K. Yamamura, eds. Pp. 19-76. Oxford: Oxford University Press. 
Porter, Michael E., and Hirotaka Takeuchi

1999 Fixing What Really Ails Japan. Foreign Affairs 78(3):66-81.

Rabinow, Paul

1989 French Modern: Norms and Forms of the Social Environment. Cambridge, MA: MIT Press.

Riles, Annelise

2000 The Network Inside Out. Ann Arbor: University of Michigan Press.

Rohlen, Thomas P.

1974 For Harmony and Strength: Japanese White-Collar Organization in Anthropological Perspective. Berkeley: University of California Press.

Roszak, Theodore

1969 The Making of a Counter Culture: Reflections on the Technocratic Society and Its Youthful Opposition. Garden City, NY: Doubleday.

Sahlins, Marshall

1996 The Sadness of Sweetness: The Native Anthropology of Western Cosmology. Current Anthropology 37(3):395-428.

Sato, Makoto

1998 Central Bank Targets Financial System Risk: Plan to Introduce Real-Time Settlement Forces Restructuring. Nikkei Weekly, September 21: 1.

Schaede, Ulrike

1995 The "Old Boy" Network and Government-Business Relationships in Japan. Journal of Japanese Studies 21(2): 293-317.

Schwartz, Frank J.

1998 Advice and Consent: The Politics of Consultation in Japan. Cambridge: Cambridge University Press.

Stinchcombe, Arthur L.

2001 When Formality Works: Authority and Abstraction in Law and Organizations. Chicago: University of Chicago Press.

Strathern, Marilyn

1988 The Gender of the Gift: Problems with Women and Problems with Society in Melanesia. Berkeley: University of California Press.

2000 Audit Cultures: Anthropological Studies in Accountability, Ethics, and the Academy. London: Routledge.

Thrift, Nigel

1996 Shut Up and Dance, or, Is the World Economy Knowable? In The Global Economy in Transition. P. W. Daniels and W. F. Lever, eds. Pp. 11-23. Essex, UK: Longman.

Tobioka, Ken

1993 Japan's Matrix of Nature, Culture, and Technology. In Japanese Business: Cultural Perspectives. Subhash Durlabhji and Norton E. Marks, eds. Pp. 31-42. Albany: State University of New York Press.

Traweek, Sharon

1999 Faultlines. In Doing Science + Culture. Roddey Reid and Sharon Traweek, eds. Pp. 21-48. New York: Routledge.

Tsutsui, William M.

1998 Manufacturing Ideology: Scientific Management in
Twentieth-Century Japan. Princeton: Princeton University Press.

Ueno, Chizuko

1988 The Japanese Women's Movement: The Counter-Values to Industrialism. In The Japanese Trajectory: Modernization and Beyond. Gavan McCormack and Yoshio Sugimoto, eds. Pp. 167-185. Cambridge: Cambridge University Press.

1994 Kindai kazoku no seiritsu to shåuen. Tokyo: Iwanami Shoten.

Uno, Kathleen S.

1999 Passages to Modernity: Motherhood, Childhood, and Social Reform in Early Twentieth Century Japan. Honolulu: University of Hawai'i Press.

Valverde, Mariana

2003 Law's Dream of a Common Knowledge. Princeton: Princeton University Press.

VanHoose, David D.

1991 Bank Behavior, Interest Rate Determination, and Monetary Policy in a Financial System with an Intraday Federal Funds Market. Journal of Banking and Finance 15:343-365.

Walzer, Michael

1984 Welfare, Membership and Need. In Liberalism and Its Critics. Michael J. Sandel, ed. Pp. 200-218. New York: New York University Press.

Weber, Max

1966 Max Weber on Law in Economy and Society. Max Rheinstein, ed. Cambridge, MA: Harvard University Press.

Weber, Max, and S. N. Eisenstadt

1968 Max Weber on Charisma and Institution Building: Selected Papers. Chicago: University of Chicago Press.

West, Harry G., and Todd Sanders

2003 Transparency and Conspiracy: Ethnographies of Suspicion in the New World Order. Durham, NC: Duke University Press.

Weston, Kath

2002 Gender in Real Time: Power and Transcience in a Visual Age. New York: Routledge.

Winner, Langdon

1977 Autonomous Technology: Technics-Out-of-Control as a Theme in Political Thought. Cambridge, MA: MIT Press.

accepted June 19, 2002

final version submitted February 5, 2004

Annelise Riles

Department of Anthropology

Cornell University

McGraw Hall

Ithaca, NY 14853

ar254@cornell.edu 